Nina Witoszek

SUM, Oslo University

Norway

Ninawitoszek@sum.uio.no

\title{
Teaching Sustainability in Norway, China and Ghana: Challenges to the UN Programme $^{1}$
}

\begin{abstract}
The article compares how the UN-initiated education for sustainable development (ESD) has fared in three seemingly dissimilar countries: Norway, a wealthy, 'post-materialist' liberal democracy, Ghana, a developing democratic country, and China, a fast catching-up, centrallysteered economy. The study - based on an analysis of national ESD programmes, schoolbooks and qualitative interviews with teachers and students - discusses some of the pivotal reasons for the decline in ESD schooling in all three countries. It also explores surprising 'archipelagos of pedagogical innovation', as shown by one of the high schools in Ghana. Our conclusions are that, apart from specific, cultural and political contexts which influence ESD, students' socio-environmental literacy in the examined countries has been affected by an ever more pervasive competitive and neoliberal mindset. Further, in all three cases, the agenda of 'sustainable development' suffers from a 'narrative and mythical deficit': a lack of a mobilizing story, the absence of which reduces the attractiveness of sustainability ideals and inhibits their empowering potential.
\end{abstract}

\section{Sustainability on trial}

In the 2012 follow-up to the international classic in global pessimism, The Limits to Growth (1976), Jørgen Randers argues that the world today has all the necessary resources to meet the challenges connected to climate shift, food scarcity, poverty, and energy crises (2052: A Global Forecast, 2012). We can do so with negligible short-term costs and massive long-term benefits, he says. The paradox is that 'people can tackle the crisis but they will not do it. And they will not do it because what is at stake is a socio-cultural transformation which is either too sluggish or too unimaginative, arrested by public inertia, and opposed by vested interests' (Randers 2014).

\footnotetext{
${ }^{1}$ This article has been part of the research project CERES21 financed by the Norwegian Research Council in the period 2008-2013. See Ceres21.org
} 
Implicit in this melancholy conclusion, and in countless other diagnoses of the ailments of the 'Age of the Anthropocene', is a call for a paradigm shift in modern education: the most influential arena of social and environmental literacy. The 'multiple modernities' which have been the fundament of this education (Eisenstadt 2000:3) have emphasized the separation of humans from nature, independent inquiry, individual autonomy and freedom, the idea of progress, and the benefits of the industrial revolution. What is needed now is a passage to a new phase of modernity, one which reclaims humanity's connection with nature that was allegedly lost during the Enlightenment. But to invite the banished oikos (natural household) back into an ever more competitive and neoliberal modernity is a demanding project.

To mention but a few issues often raised in the ongoing discussion on ESD, sustainable development is founded on the ideal of a wobbly, if unrealistic, balance between the imperatives of development on the one hand, and environmental concerns on the other (e.g. Newig et al 2008). Furthermore, the very concept of sustainability has been often perceived as nebulous United Nations-speak, based on high-minded rhetoric and frequently divorced from concrete action (e.g. Robottom 2012: 162). Finally, teaching sustainable development poses extraordinary demands on teachers' competence. So far, even the UN's 'Decade of Education for Sustainable Development' has failed to craft a holistic and interdisciplinary teacher's education and a corresponding school curriculum that would foster new types of knowledge, values, skills, and practices (Gough and Scott 2003; Ott 2013). ${ }^{2}$ As a result, the concept of sustainability is, on its own, a poor indicator of a society's transition to a sustainable future, even though it is increasingly made use of (Jorgensen 2003: 388; Sipos et al 2008: 70; Sterling 2008: 18).

So is teaching sustainability like teaching a course on 'corporate social responsibility' - mere pedagogical window dressing? Or a kind of moral tribute paid to a guilty conscience, while governments and electorates obsess about economic growth and a competitive mindset rules supreme? I argue that cultural innovation for a sustainable future - of which ESD is a part - does not merely involve challenging modernity's reigning narratives, values, and routines; it demands reimagining existing ideas and visions of sustainable development as a tool of environmental and social renewal. The key question I wish to ask, then, is in what

\footnotetext{
${ }^{2}$ UNCED's ambition of creating an interdisciplinary field of education has been clearly stated: 'To be effective, environment and development education should deal with the dynamics of both the physical/biological and socio-economic environment and human (which may include spiritual) development, should be integrated in all disciplines, and should employ formal and non-formal methods and effective means of communication' (UNCED 1992: 33).
} 
ways Western and non-Western high schools teach sustainability, understood not just as a socio-environmental imperative, but as a compelling story which offers the prospect of a better world to the younger generation? And more specifically, how is this story told in Norway - one of the most affluent, and seemingly 'green', liberal democracies of the world: a locus of resplendent, pristine nature, and a society with a relatively high level of environmental literacy, strong democratic and humanist traditions, and generous welfare provisions? Can we further illuminate the array of problems bedeviling education for a sustainable future by comparing the Norwegian secondary school curriculum with ESD in a catching-up economy such as China, or in Ghana - a developing country with a fledgling petro-economy?

The choice of these three countries is not accidental. Ghana, China and Norway represent three different types of socio-political development in the globalized world, and hence are good test cases of the ways in which specific social and cultural contexts influence ESD. Ghana is an intriguing example of a developing country which represents political and cultural 'liminality': on the one hand, it is a relatively stable and pluralist African democracy with newly discovered oil wealth, perceived as a potential source of future economic prosperity. On the other, Ghana continues to be a poor and backward society whose education is marked both by limited resources and the relics of the 'postcolonial mind syndrome' (Memmi 1973; 1991). However, as I will show below, Ghana also displays surprising pockets of innovative sustainable thinking in private elite schooling.

China is also a site of socio-environmental dualities, though stemming from different conditions. The top-down communist regime tightly controls the content of education, including discussion of development and the environment in school curricula. As the world's greatest producer of $\mathrm{CO}_{2}$ emissions, struggling with lethal pollution at home, China now drives a double, 'carbon and green locomotive' (Midttun and Witoszek 2015): on the one hand it invests in massive, carbon-based economic growth, while on the other, it has, in the last decade, defined the cutting edge of advanced renewable technologies, making them ever cheaper the world over. The paradox of China - a mammoth polluter, but also a global environmental frontrunner - is a source of puzzling speculation. Influential environmentalists, such as Jørgen Randers (quoted above), believe only a China-style, highly centralized approach to the climate challenge can derail environmental Armageddon (Martiniusen 2012).

Norway is in perfect opposition to both Ghana and China. Not only is it one of the richest liberal democracies on the planet, but in UN rankings, it has consistently figured as the 
top country regarding quality of life, gender equality, low corruption, sophisticated ideas and the practice of citizenship, as well as high levels of social voluntarism (Hellevik 2008). More importantly in our context, Norway champions a relatively decentralized educational system which gives teachers plenty of room to freely choose their textbooks and mold the contents of education. However, the country also has a Janus face. It boasts outstanding green reformers: the founder of Deep Ecology, Arne Naess, and sustainability's chief codifier Gro Harlem Brundtland (1987). But at the same time, due to its oil-based economy, Norway makes a major contribution to humanity's ecological footprint - an incongruity that clashes with Norwegians' deeply felt nature-based identity (Witoszek 2011).

There is yet another reason for having a closer look at ESD in the three contrasting societies. Apart from examining how specific socio-cultural contexts influence models of education for a sustainable future, it is worth asking to what extent economic and political globalization - which includes not just the UN focus on sustainability but also a shared economic growth fetish - influences the contents of environmental education on three continents. What are the shared areas of concern?

This article, building on a comparative study undertaken by an international team of researchers ${ }^{3}$, explores the progress of sustainability and the level of socio-environmental reflexivity in Norwegian, Chinese and Ghanaian secondary schools in the period 2013-2014. To update our results, we briefly surveyed educational roadmaps in these countries in 2015 as well. The research team used a combination of methods, ranging from an analysis of national educational white papers and school curricula, to participant observation and qualitative interviews. The interviews were with ten teachers and ten students aged 15-16 from two selected high schools in each country. To de-familiarize a tired debate on the shortcomings and virtues of ESD - and bring fresh insights into our comparative study of ESD curricula this study has used Jerome Bruner's 'narrative psychology' for inspiration (Bruner 1986; Bruner 2002). Bruner's approach invites a focus on sustainable development understood less as a set of policy directives and more as a world-making narrative. According to Bruner, stories and narratives - a culture's 'coin and currency' (Bruner 2002: 15) - provide the least disruptive way of passing on a culture and forging a new one. 'Through narrative, we construct, reconstruct, in some ways reinvent yesterday and tomorrow. Memory and imagination fuse in the process. [A story] has the power to change our habits of conceiving what is real and what is canonical' (Bruner 2002:93-94). In short, stories are not just crucial in

\footnotetext{
${ }^{3}$ This article draws on data collected by master students Kari Laumann and Ellie Ribeiro Koelch, and research assistants Emma Holm, Abdulai Jakalia and Su Dongxia (see references).
} 
shaping our realities; they enable the art of imagining and implementing a sustainable future. No transition to an 'ecological modernity' is possible without fundamental changes in our conceptions of knowledge, thought, learning - and storytelling. When education narrows its scope of interpretive inquiry and forsakes its visionary, narrative vigor, it reduces a culture's ability to adapt to change even if the imperative of attitudinal change is quite apparent and demanding of immediate action.

The results of our comparative journey - although pointing to different culturalpolitical impediments and featuring different aspirations - reveal many common dilemmas. But, above all, they signal a shared, underlying need for reimagining the very concept of sustainable development - the child of the $20^{\text {th }}$ century's carbon modernity.

\section{Teaching sustainability in the 'world's best country'.}

In 2015 Norway was ranked, for the $13^{\text {th }}$ time since 2001 , as the 'best country to live in', by the UN Human Development Index. ${ }^{4}$ Ongoing research on the 'Norwegian model' confirms that Norwegians have entered a post-materialist age - where both extraordinary wealth and a lack of existential constraints enable the majority of citizens to both enjoy a high quality of life and experience a 'transition from a welfare- to a well-being state' (Midttun and Witoszek 2016). In addition, Norway touts a pristine, dramatic and abounding natural environment, which has shaped national identity and the perception of nature's 'ancestral home' (Witoszek 1998; 2011). Norway's high standing on world development criteria thus begs the question of whether these impeccable socio-cultural and political credentials are matched by an equally impressive model of education for a sustainable future.

The beginnings of educational transformation were promising. In 1989, the Norwegian government issued "White Paper no. 46: On Environment and Development" as a response to the Brundtland Report. As a result, an obligatory course called 'Nature, Society and the Environment' was introduced into teachers' education in 1992. However, ten years on, the subject was erased from the teachers' curriculum with little resistance either from politicians or teachers themselves. It has been argued that the forging of a systematic teacher training programme in ESD was crippled partly because of the high degree of interdisciplinary competence demanded from teachers, but also as a result of Norway's shift to a prosperous oil-based economy (Saetre 2002: 397). This shift changed people's consumption patterns and

\footnotetext{
${ }^{4}$ The UNDP assessment, focused on health, equality and social justice, access to knowledge, and high standard of living, highlights quality of life and downplays gross national product, though Norway scores high in the latter category as well. See http://en.wikipedia.org/wiki/Human_Development_Index
} 
reoriented educational discourse and aspirations away from what can be described as an 'ecohumanist ethos' (Witoszek 2011) and towards a more competitive and efficiency-centered conception of Norway as a serious global economic player.

According to the International Association for the Evaluation of Educational Achievement (IESA 2002), in the last decade of the twentieth century, Norwegian textbooks educated secondary school pupils to feel strongly about equal rights, be supportive of ethnic minorities and, in value-charged discussions, show respectful disagreement in the classroom (IAEEA 2002). However, an evaluation of the efforts to implement ESD in the postBrundtland period, undertaken in 2005 by MiljøUnderVisning i Norden (Environmental Education in the North), shows that sustainability was increasingly perceived as 'risky' or 'controversial' by most secondary school teachers and students. In 2012, the Norwegian UNESCO committee admitted that the advocates of education for sustainability had not succeeded in overcoming an array of cognitive, cultural, and policy-related hurdles (Ott 2014: 21).

There are many indications that in the $21^{\text {st }}$ century, Norwegians have become particularly adept at cultivating cognitive dissonance - i.e. accepting Norway's status as a 'mecca of environmentalism' and as a successful, even 'virtuous' oil economy which generates both unprecedented and relatively fairly distributed social welfare and affluence. The Norwegian curriculum reflects these tensions and paradoxes. On the one hand, one of the popular Norwegian textbooks on social science, Underveis ('On the Way'; 2017; 2014), highlights the social aspect of sustainability: the 'good society,' human rights, women's rights, and the links between colonization, industrialization and the global economy and poverty and the unequal distribution of resources. In addition, the discussion of climate crisis figures strongly in the geography textbook (Birkenes and Østensen 2014). But the level of self-reflexivity on display in these textbooks points to puzzling lacunas and paradoxes. Firstly, dramatic effects of global warming - up until the time this article was written - tend to be presented as occurring out there, having nothing to do with Norway. The connection between the carbon-based economy and the looming environmental Armageddon has only been hinted at, rather than problematized or depicted as threatening Norway. Social science textbooks such as Radar (Andresen and Henningsen 2013; 2015) illustrate Norwegian priorities: the themes of multiculturalism and aboriginal people are given 30 pages in total. Sustainable development, climate and the environment are squeezed into three pages in the section on 'International Systems,' while the main environmental challenges are conveyed more in the form of bullet points than through informed discussion. 
Compared with social science textbooks, Norwegian natural science has treated both climate change and environmental destruction extensively, but from a particularly ethnocentric perspective. Strikingly, in Natural Science Level 8-10 in the popular Tellus series (2007; 2015), Norway's extraction of oil and gas has been framed in largely positive terms. The choice of glossy tropes in Chapter 6 on oil and gas as 'treasures outside the Norwegian coast' is telling. Although the chapter does mention the negative environmental impact of the oil industry on climate, the focus on the beneficial aspects of carbon economy takes precedence over discussion of environmental dilemmas. 'Treasure' and 'fairy tale' are pivotal metaphors in this chapter, and finding oil on Christmas Eve in 1969 is described as the 'biggest Christmas present ever' (p.173). Thus, despite a growing hospitality to the climate problematique, even the more socially critical textbooks (e.g. van Marion et al 2013) embrace a world model still grounded in the old and optimistic carbon modernity. The story goes as follows: Gas and oil extraction pose some challenges, but they can be overcome with adequate, environmentally friendly technology. The renewables revolution is just around the corner, nature is a resource to be exploited for human benefit and economic profit; we just need to be smarter at inventing technologies which reduce environmental depletion, make oilextraction environmentally friendly and - in terms of social practice - get people to recycle their garbage and use public transport more.

To sum up: while the key narratives in the Norwegian textbooks in the natural and social sciences promote knowledge about environmental challenges, they are undisturbed by any serious problem-framing of Norwegian oil-based wealth. Students are trained in cognitive dualism: at home they are taught to value and enjoy unspoiled nature and outdoor life, while at school they are told to stoically accept that the basis of Norway's success has been the 'oil adventure.' Even the dominance of the Green Party in Oslo City Council since 2015 , has been felt more in the number of bicycle paths than in any dramatic changes in the culture and mindset propagated by the secondary school curricula.

Most of the interviewed teachers agreed that, in spite of an extra environmental component added to the textbooks in the natural sciences and geography, there has been little or no investment in innovative 'green pedagogy' that would train teachers in a more holistic approach to the environmental crisis (Ribeiro 2014). More interestingly, our interviewees

\footnotetext{
${ }^{5}$ As late as March 2016, the Norwegian Prime Minister Erna Solberg insisted that despite the oil crisis, the Norwegian 'oil adventure is not finished; it will continue in many decades'. She defined the way forward in terms of technology and job-transformation. https://www.regjeringen.no/no/aktuelt/statsminister-erna-solbergapnet-norsk-olje-og-gass-sin-arskonferanse/id2479156/.
} 
insisted that there was a contradiction between the declared climate concern and a growing school fixation on performance in Pisa rankings. As one of the teachers put it: 'We are supposed to ensure good results in tests, not to teach students how to save the planet' (Ribeiro 2014: 21).

The feedback from students confirms teachers' perceptions. Although all expressed their concern about the climate crisis, the majority held that the teaching of environmental values at their school was only moderately important; there were other priorities (e.g. human rights, poverty, or social inequality). Though the climate crisis was perceived as one of the most pivotal challenges of our time, sustainability as a concept was defined as 'uninspiring,' 'vague', 'utopian' - and lacking an attractive, mobilizing story. ${ }^{6}$ As one of the students put it:

Actually, sustainable development doesn't tell any story; it is just a set of 'commandments' about fighting poverty and pollution, becoming more Spartan in one's lifestyle, and recirculating garbage.

Most students and teachers argued that the 'silosized' approach to sustainable development taught in bits and footnotes in geography, social science or biology lessons - has led to a perception that the climate shift is the business of scientists and technologists, the job of governments, or the master-task of NGOs. Although the majority declared that, ultimately, they felt personally responsible for the predicament of their local environment, they were sceptical about the consequences of changes in personal consumption patterns. One of the graduates of the elite Norwegian secondary school declared:

Let's be realistic, Arne Naess's biocentric egalitarianism is utopian. Besides, even if we introduce deep ecology in Norway, and even if all our youth stops taking planes, starts recycling and buying green, it will only be a drop in the ocean (Witoszek 2014).

One of our questions was: what can be done to teach sustainability in a more compelling fashion? Teachers called for more interdisciplinarity in teachers' education, more holistic schoolbooks, engagement with practitioners on the ground, and the introduction of ecological ethics into the school curricula. Students argued that the vision of living in a sustainable fashion was not made attractive enough in schoolbooks; rather it was occasionally given a lift via social media:

Twitter and Facebook make it trendy to be green because of some cultural idol [...] is green. But sustainability doesn't give you any concrete vision of a better world; it means that we are supposed to ask our parents to buy electric cars, go vegetarian, and support fair trade and the environmental NGOs (Witoszek 2014).

\footnotetext{
${ }^{6}$ These comments and definitions were offered by some twelve Norwegian high school graduates at the first seminar at the Centre for Development and the Environment, the University of Oslo in the autumn of 2014.
} 
Has the relatively frictionless life in a secure, oil-rich welfare state, and the unique access to the beauty of the land, quenched the desire for a more sustainable world? One teacher's comment offered us food for thought:

Clearly we need a new green civilization, but many think that we can get it by buying Tesla cars [...] So yes, we do need a really good story that will not scare students but make them act... This would have to be appealing narratives which would make the students crave a new and different world with a new galleon of heroes.[...] Here I think the capitalists are more inventive than we pedagogues are (Witoszek 2014).

Ironically, today the most innovative thinking with regard to forging a sustainable future takes place not in Norwegian schools, but in the business sector. The gradual transition to a post-oil economy stimulated by plummeting oil prices, as well as daring ideas about links between business, sustainability and peace, have generated an effervescence - not just of bold projects, but of protagonists and visions that tell a mobilizing - and profitable - story of a more sustainable world. ${ }^{7}$

\section{Teaching sustainability against the tyranny of tests: the case of China}

According to a review of Chinese literature on sustainability education from 1979 to 2005 (Tian 2008; Ting 2014), China was slow to recognize its environmental problems. Elements of environmental education were introduced only after the 1992 Rio summit in the shape of the National Action Guideline for Environmental Propaganda and Education (1996). However, over the years, very much as in Norway, environmental concerns were steadily eclipsed by ideas of ecological modernization - a trend evident in the decrease of Chinese papers on environmental education after 2004 (Tian, 2008). In the first decade of the Chinese implementation of the UN-defined ESD (1992-2002), there were three major shifts: a transition from 'an international concept of ESD' to a more indigenous Chinese definition of the concept (i.e. emphasis on the elimination of poverty via unhindered economic growth); a passage from intervention and action research to public policy-making; and from schoolbased innovation to school-community partnership building (Du, 2008). ${ }^{8}$

The preamble of the official Outline of China's National Plan for Medium and Longterm Education Reform and Development 2010-2020 (2010) states that, 'in accordance with

\footnotetext{
${ }^{7}$ One of them is the annual Oslo 'Business for Peace' award given annually to 'businessworthy', sustainable and peace-forging economic innovations across the world. See http://businessforpeace.no/

${ }^{8} \mathrm{Du}$, Y. (2008). A decade review on ESD in China. Journal on Education for Sustainable Development in China, 1, 1-2.
} 
the strategic arrangement of the 17th Communist Party of China National Congress,' the main goal of Chinese education is to 'enhance citizens' overall life quality, boost educational development in a scientific way, and speed up socialist modernization' (Outline: 5). There is only a fleeting reference to 'sustainable development' in the passage which runs: 'Due attention shall be paid to education in personal and campus safety, human life, national defense, and sustainable development' (Outline: 11$).{ }^{9}$ None of these goals are spelled out in more detail.

At the initial stage of our research, we were invited to a 'demonstration school' in Jingshan, which was supposed to work exclusively on developing education on sustainable development. ${ }^{10}$ But when gently pressed for factual information, one of the pedagogues responsible for the programme confessed: 'We have only had a public presentation and a couple of dissertations so far.' [...] 'We know we should create more input, but we are reluctant to do that because there is little actual encouragement and no clear guidelines.' (Dongxia 2013c: 16). Later, one 'bold' teacher at Jingshan declared:

Many schools have created fake websites of the ESD program. They don't lead to any actual implementation of the professed objectives. Sustainable development is just a beautiful slogan, an empty verbiage, which may improve your reputation. [But] our governors put unhinged economic growth in the first place because their performance is measured and rewarded by the level of economic development, not by the level of pollution (Dongxia 2013c: 11).

Our interviewees at the high-ranking secondary school in Xiehe, in the province of Guangzhou, told us that sustainable development was discussed mainly in biology and geography classes and via extracurricular courses known as an 'eco-campus programme'. Since this programme was voluntary and time-consuming, students had to get their parents' written permission to take it. The three textbooks used at the eco-campus included students' and teachers' observations on the relation between humans and nature, reports on school experiments, a review of Xiehe plant resources, and a 'hypothetical' test on sustainability. After each article, the book listed questions designed to help students understand the main points and give correct answers. Shining through these books was the propaganda of success. In the introduction to the series, we read:

The books' motif is to tell stories of how Xiehe faculties and students unite together to build up their eco-campus. During this process, students interact with one another,

\footnotetext{
${ }^{9}$ There are three more references to ESD in the Outline, but none elaborates on the subject.

${ }^{10}$ Beijing's Jingshan School has 2,400 students in total, and includes primary, junior and high school levels.
} 
with their teachers and nature, and the built environment. In a happy mood, they successfully learn about the SD concept, and become more aware of the surroundings to see how the concept that sustainability makes our lives better (Dongxia 2013c:1).

Interestingly, in the group of ten interviewed teachers, there were two 'dissident' types, who openly expressed their frustration with the authorities' indifference to the acute environmental crisis in China. The rest belonged to the more prevalent passive-conformist cohort, whose outlook was captured in this fragment of conversation:

Su (interviewer): Can you tell me your opinion on carrying out the ESD [Education for Sustainable Development] policy at schools?

Teacher Z: What can I say.[...] I am not a dean or a member of higher department.

Su: OK, try to tell me more what the teachers want [with regard to ESD].

Z: More instructions and training are needed. ESD shouldn't be restricted to biology class. Teachers are waiting for instructions; it is not up to them to decide. (Dongxia 2013c: 3)

More importantly, the Chinese teachers identified two major challenges to teaching sustainable development. The first was the lack of interdisciplinary approach to sustainability - the deficit also signaled by the Norwegian teachers: 'Conducting an ESD programme poses a real challenge for us, because we need to be comprehensive experts. We've got to know many subjects: chemistry, biology, social development, culture, etc.' (Dongxia 2013c: 9). But, in the eyes of many teachers, the most prohibitive obstacle to teaching sustainable development was the spectre of the National Entrance Examination that haunts all Chinese pedagogues and students. Since it determines whether a secondary school graduate is admitted to university, there is a grueling schedule tied to the pre-exam study which does not leave any time for extracurricular ESD. If an ordinary Norwegian pupil spends on average about 6 hours a day on courses and homework, her Chinese counterpart studies for 12 hours a day or more. As one student relayed: 'I get up at 6:20... On the way [to school], I usually review my homework, if I'm not exhausted from the previous night of studying. In the evening, after the 21:45 night classes, I still continue to study... often until 3 in the morning' (Dongxia 2013d: 9).

'Chinese education is effective but it is about fabricating exam-robots', one critical teacher declared (Dongxia 2013 c: 1). This explains why most interviewed pupils at Xiehe were far from enthusiastic about the eco-campus courses: 
Student 1: I think global warming is a very vague concept. I am just a normal person. It is not my obligation to worry about it.

Student 2: The National Entrance Examination is everything in China's educational system. I am a victim of it. [...] I don't want to waste my time on ESD.

There was a broad student agreement on their priorities: 'We can cure the environment only after we get rich' (Dongxia 2013b: 4).

Clearly, in the Chinese case, joining the eco-campus was not just the expression of cognitive passion or an idealist stance: it was virtually an act of heroism. But there were - and still are - pupils who take courses on sustainability in spite of the cost. ${ }^{11}$ As one of them put it, 'these courses can't bring me any actual benefits, like improving my scores. But I take them because in China environmental pollution is a problem, the teachers are so engaged.... and there is so little fun in Chinese education!' (Dongxia 2013b: 1).

Half of the interviewed Chinese students were not sure what sustainable development meant, and did not associate it with any 'story,' mobilizing or otherwise. For the majority it was about 'a government's politics or 'just one more question in a test'. The eco-campus students suggested that ESD tells a 'story that small-scale improvements are possible': 'We can meet the requirements of Ten Do-s: switch off the light when you leave; save electricity; save water; use LED lights; use more public transport and more bicycles; introduce a programme on how to manage gardens, use more outdoor classes.' But when we asked whether the Ten Do-s were good enough as a story to make people act, the students became confused. We reformulated the question: 'Is the story about a sustainable China as good a story as the dream about China as a powerful nation?' The answer was unequivocal: The pupils were studying to make China even greater. True, they expressed worry - at least at the level of rhetoric - about the environmental crisis, high $\mathrm{CO}_{2}$ emissions in China, and the dearth of environmental awareness. But they also agreed that ESD was 'important but unprofitable'.

The two educational environments which we studied in no way represent the complex - and fast changing - landscape of Chinese schooling initiatives. What we noted was that even in the test-and-study-obsessed system there are islands of creative interdisciplinary thinking which forge a pro-environmental and pro-social mindset. A glimpse of such innovation was offered by a project initiated by a history teacher who, in her words,

\footnotetext{
${ }^{11}$ We updated our findings at the end of 2015 by having a skype conference with our collaborators and a teacher informant.
} 
'piggybacked on the archeology class' and mobilized five students to do research on a cement factory near their school which was closed down.

Not only did we find lots of cultural relics of [the] Han Dynasty; the students became aware of the relationship between the cement factory, humans and the destruction of the natural environment![...] And then we sat together and wrote a letter to the government praising it for closing down a polluting factory and suggesting an exhibition of the cultural relics we found. By doing this the students understood that in order to do something about culture and the environment we must cooperate, not just compete.' (Dongxia 2013d: 5).

\section{Ghana: A 'windowless basement' versus a 'room with a view'}

The stirrings of ESD in Ghana go back the 2002 Syllabus Development Workshop in Ajumako designed to draft key issues in education for sustainability. ${ }^{12}$ Like the Norwegians and the Chinese, the Ghanaians do not define sustainable development as a separate subject but integrate it into several teaching areas (especially agriculture and social studies). They link it to goals such as 'modernization of obsolete cultural practices', improved health, counteracting desertification and deforestation, promoting conflict resolution and children's rights, even to the introduction of new careers. The Ghanaian national policy on ESD as formulated by the National Report of Ghana on the Development of Education (2004) states that:

In addition to the integration of selected important themes within syllabuses, themes like HIV/Aids, Environmental Degradation, Sustainable Development,

Communication and other Psycho-Social skills such as assertiveness and confidence building, etc, have been integrated into several subjects. It is hoped that the integration process adopted will help to change the nature of the Ghanaian towards superstition, witchcraft and other important attitude-building themes that will help build a new type of Ghanaian with knowledge, positive attitudes and high thinking that will assist in the rapid, socio-economic growth of the country. ${ }^{13}$

In 2010, the Ghanaian authorities also formulated their national Climate Change Adaptation Strategy, financed by UNDP, which advocates introducing climate change education into the school curriculum and improving environmental and health education in rural areas. ${ }^{14}$ But in spite of the rhetoric around environmental concerns, most educated Ghanaians we spoke to insisted they were 'unapologetically for growth' (CERES21, 2014). As late as 2016,

\footnotetext{
${ }^{12}$ The workshop was followed by subsequent teacher training program at the Institute of Management, Planning, and Administration in Accra. http://www.ibe.unesco.org/International/ICE47/English/Natreps/reports/ghana.pdf, p 26.

${ }^{13} \mathrm{http} / / / \mathrm{www}$.ibe.unesco.org/International/ICE47/English/Natreps/reports/ghana.pdf, p 27.

14 http://www.adaptation-

undp.org/sites/default/files/downloads/ghana_national_climate_change_adaptation_strategy_nccas.pdf
} 
modernizing, rather than ecological aspirations, continued to dominate the Ghanaian curriculum. ${ }^{15}$

At the start of our project we were told by colleagues that 'Ghana is like hell and heaven with regard to teaching sustainability.' To better illuminate the tension between these two realms, we were advised to visit both educational 'hells' and 'heavens'. We interviewed students and teachers from an 'ordinary' secondary school in Winnabi outside Accra, and from an elitist, private school in Tema in central Ghana. In each case, apart from reviewing the curriculum, we talked to ten students and ten teachers (the latter including tutors of biology, chemistry, biology, geography, IT, and 'Creativity, Action \& Service').

Our first case - The Winneba Senior High School - introduced itself on its website as a 'school with a touch of excellence.' ${ }^{16}$ The deputy headmaster explained that the popular Aki-Ola textbook series used by the school included Social Studies and New Integrated Science (1997) each offering 'satisfactory information on sustainable development' (Jakalia 2013). We opened both books; they included subsections that mentioned the concept of sustainable development in passing in chapters on 'Resources Utilization and Development in Ghana' and 'Our Physical Environment, and Energy' (Quatery 2000). When pressed, the deputy headmaster admitted that, actually, the teaching of sustainability at Winneba was haphazard, time-consuming, and in need of new textbooks for which there was no money. The school boasted an agricultural profile and the guidelines in its ESD program suggested inviting sustainability practitioners to address the class. However, the guidelines 'were not followed because of time constraints.' We were told that some teachers attended special programs on sustainability - a course on population growth for example - but there was no clear policy on ESD. 'The environmental crisis and climate change are largely discussed at national and local seminars,' the schoolmaster said. And, 'If you really ask me, most students learn about sustainable development from the media, especially the local radio' (Jakalia 2013: 2).

The lack of resources and qualified pedagogues, and no clear educational policy from the government have yielded what can be called a 'stoic helplessness' on the part of teachers.

\footnotetext{
15 In the civic-minded NewDay TV 'Interview with SOS Ghana on quality education for a sustainable future' $(24 / 3 / 2016),{ }^{15}$ the concept of ESD is synonymous with a 'quality future' and 'quality education'. There is no mention of the needs of the environment throughout the interview; what is highlighted is a model of schooling which has as its aim 'identifying [the child's] 'hidden talent which can be useful to the society, fighting poverty, and providing children to realize their potential' (NewDay 2016).

${ }^{16} \mathrm{http}: / /$ winnesec.com/
} 
When asked for concrete examples of how education for a sustainable future was implemented at the school, a young geography teacher struggled to explain:

During lessons, students are usually fanning themselves due to the high temperatures, and we explain to them that this is because of our impact on the environment. And we tell them about the environmental effects of mining, which we call a 'cancer of Ghana.' But normally, after teaching, we usually ask them [the students] to go on the internet for more information. The problem is that we often have electricity breakdowns, so the access to internet is intermittent (Jakalia 2013: 5).

The interviews with the students further confirmed the impression of only helter-skelter guidance: Some pupils identified sustainable development with 'the process of maintaining our infrastructure in order to improve our standards of living.' Others saw it as a 'process of keeping a particular government development project functioning very effectively' (Jakalia 2013: 3, 10).

Most Winneba students insisted that sustainability was taught - if it was taught - in too abstract a manner; there needed to be more practical classes. But like the Norwegian students, the young Ghanaians looked upon the environmental predicament as their own personal responsibility: 'you do not drop litter to pick it later' (Jakalia 2013: 8). All agreed that environmental protection in Ghana should be given priority over economic growth - or at least there should be equilibrium between the two. Some interviewees suggested that the government did not address climate challenges because of the country's colonial heritage and more pressing problems such as inequality and poverty. As one of the teachers put it:

The main source of Ghanaian national income in 2013 was the export of timber, but we do not practice re-afforestation because we expect revenues from oil. So we have less and less forest and more and more oil which is unsustainable; we should be investing in solar energy." (Jakalia 2013:9). ${ }^{17}$

When asked about the mobilizing potential of the story of sustainable development both students and teachers agreed that, as a narrative, it was 'confused' and 'not very visionary'. Most of the teachers were skeptical about squaring development and the environment. One of them observed:

There are some positive environmental stories, like Wangari Maathai planting trees to improve climate, but then most of our students want good jobs which are not about planting trees. The story which makes out students tick is that Ghana's better future is about economic development which is connected to growth and oil extraction. So in

\footnotetext{
${ }^{17}$ Theoretically, this vicious circle should have ended in 2014, when oil prices plummeted and solar energy became significantly cheaper. But at the 'touching ground' conference with one of our Ghanaian collaborators at the end of 2015, we were told that Ghana showed few signs of improvement in terms of green transition.
} 
the end we see that our sustainable development is no so sustainable but we live with it. (Jakalia 2013:9). ${ }^{18}$

\section{Tema school: laboratory of a sustainable future?}

Curious to see Ghanaian ESD at its best, we included in our research the Tema International School (TIS) ${ }^{19}$ - a private high school for Ghanaian students, but one with international aspirations. TIS uses Cambridge examination tests and its students are not just well-spoken but well-travelled as well. The campus reflects environmental imagination at work: one sees intelligent landscape design, exuberant flora and modern, breathing architecture. Unlike the Winnabi pupils, all Temanians we talked to displayed an extensive knowledge of sustainable development which, they said, they learned through the courses on geography, biology, social science and economy, as well as from the CAS class, which stands for 'creativity, action and service.' What was certainly novel in Tema's attempt to forge social and environmental awareness was a schooling which embraced feedback between theory and practice. One student boasted:

Last year we went to Prampram to clean beaches and visit an orphanage, so we do a lot of these things in the community to help them, and so, yeah we even had an event to heighten the awareness of the HIV/AIDS. We do all this [to] draw attention to problems with development and the environment that we see in our society (Halm 2013: 27).

The teaching of sustainability combined with training in 'civic-mindedness' seemed to be a specialty at TIS. 'As part of the IB program we are supposed to render a service to our community that is beneficial,' one student explained, 'so we visit orphanages, help people, we have funfairs - and the proceeds from these events go to the community ${ }^{20}$ (Halm 2013: 27).

Sustainability was taught most extensively through the geography course. The key textbooks - Cordington's Planet Geography (2007) and Quatery's Ghana and the Wider World (2000) were informative and included succinct and critical discussions of the concept of sustainable development. Courses were usually accompanied by slide shows, videos, posters, and other visual material that helped to illustrate the human impact on the environment. One of the teachers said:

\footnotetext{
${ }^{18}$ Theoretically, this vicious circle should have ended in 2014, when oil prices plummeted and solar energy got significantly cheaper. But at the 'touching ground' conference with one of our Ghanaian collaborators at the end of 2015, we were told that Ghana showed few signs of improvement in terms of green transition.

${ }^{20}$ Many pupils alluded to a fund-raising funfair they had organized at a newly constructed school in the poor Volta Region.
} 
I made the students watch Al Gore's 'An Inconvenient Truth.' ... Once they watched it $[\ldots]$ they became motivated. And that was not because of the future exam but because something that they want to accept and live by (Halm 2013: 31).

All interviewed students were aware of the paramount role of education - and of intellectual elites - in building a new, greener Ghana: 'I think people look to examples from above, so, as future elites, we can help prevent people throwing rubbish around.' (Halm 2013: 7).

However, asked whether they perceived sustainable development as 'a compelling story which invokes a vision of a better future', most students admitted that they understood the concept not just as one, but as many stories about 'how bad the environmental crisis is' and 'how we need to improve the situation of the poor, especially children'. They all agreed that sustainable development was couched in the UN-speak which they supported but 'did not quite own'. Interestingly, one interviewed teacher alluded to the ecological potential of local stories and traditions:

Many folk stories in traditional Ghanaian culture teach us about subsistence, sustainability and spirituality, like for example the story about Kwaku Ananse who collected all the wisdom of the earth into one bottle. We also have many [ecological] proverbs such as Tumi nyinaa ne asase: 'All power emanates from the earth.' We should be smarter in combining the latest findings about the climate crisis in science, and the educational potential of our Ghanaian folklore. I think this is something that would make our students act more effectively' (Gadzekpo 2013).

Most students were highly critical of the Ghanaian government's environmental and climate policy and were bursting with ideas as to what could be done to improve matters. One could start from obvious things like planting trees, introducing an obligatory course on the relationship between humans and their environment in primary schools, or, at the higher level, on how to stop unsustainable consumption. Some students called for a more advanced 'sensitization process' - about both building environmental consciousness and 'walking the talk'. Like the Norwegian students, the Temanians declared that they perceived the climate crisis as their own personal responsibility which required concrete action on the ground. But, unlike their Norwegian and Chinese counterparts, who were prey to either 'realism' or passivity, the Ghanaians at Tema considered themselves empowered:

I think [climate change] is my problem also because Ghana is democratic and, well, democracy is government for the people and the people for the government. So then, if I'm included and if I have a part to play in the decision making, it has to be also my problem.' (Halm, 2013:8) 
When asked about a rather ethnocentric Ghanaian perspective apparent both in their textbooks and perceptions, the students defended the local optics and interventions. 'Teaching global warming is important but we have to start here in Ghana. Why not create green jobs at home? Why not transform TIS into a model green school?' (Halm: 2013: 15).

\section{Concluding discussion}

The study we conducted on three continents offers only partial insights into what is by far a much more complex and tension-ridden pedagogical landscape. But, while our findings are not representative, they do throw some light on the dilemmas shared by many developed and developing countries. Four major hurdles to ESD present themselves. The first has to do with the continuing growth fetish in all three countries: one of carbon modernity's focal points. As a consequence, what has been missing in all schools under scrutiny is the teaching of ecological ethics. Once a popular subject in Norwegian schools, environmental education has now been eclipsed by classes on human rights, the 'rights of indigenous people' or courses on health and poverty. The Norwegian and Ghanainan school curricula reflect what has been called 'The oxymoronic goal of both promoting development through economic growth....and keeping the health of the ecosystem intact' (Kopnina 2012: 705). ${ }^{21}$ Considering the limited confines of our research, it was truly uplifting to see idealistic attempts to stir the dormant environmental consciousness in the much 'brutalized' Chinese context, but this was an exception rather than a rule.

The second hurdle to ESD is a lack of adequate teacher education that would stimulate a synergic approach to development and the environment. While teaching sustainability in a fragmented way - via classes in geography or the natural sciences - is partly justified, there is a need for an overarching holistic awareness of global problems and a corresponding innovation within teachers' education. Implicit in the Norwegian and Ghanaian teachers' and students' comments is a realization that there is no way of illuminating the clash between democratic or economic aspirations on the one hand, and sustainability objectives on the other, without a tighter interdisciplinary dialogue between the natural scientists and other disciplines.

\footnotetext{
${ }^{21}$ A similar conclusion has been drawn in a 2015 study reviewing the environmental education in China (Tion and Wang 2015). The authors criticise 'the unscientific understanding on environmental education, low-level of motivation to incorporate EE in teachings, the lack of environmental awareness, and contradiction between economic growth and environmental protection and sustainable development'.
} 
Thirdly, both Chinese and Norwegian teachers have signaled that test- and rankingobsessed schooling has partially contributed to putting the ESD agenda on the back-burner. 'Sustainability needs a cooperative effort,' one Norwegian teacher told us, 'but we are more and more programmed to compete.' This overarching global aspiration has been decried by Richard Sennett in his study Together: The Rituals, Pleasures and Politics of Cooperation (2012). Cooperation, unlike the more insular and particularist 'solidarity', involves transcending selfish interests in the name of a higher, public good (Sennett: 287). Sennett insists that children should be 'endowed to cooperate more than institutions allow' and calls for a model of teaching that gives priority to the overriding importance of social cooperation in moving to a more sustainable world (Sennett: 141). This does not necessarily mean denying the contingent benefits of competition or exams. But a wise balance of competition the necessary 'hormone' of innovation and progress - and training in pro-sociality is a sine qua non condition of tackling all crises, including climate change. ${ }^{22}$

One of the most disturbing conclusions of this study has been that ESD's 'gallant story' - as it figures in all three national educational programmes - seems to have minimal impact on the actual environmental practice on the ground. Does the rift between educational aspirations and a stubborn anti-ecological modernity mean that modern education systems are rendered powerless, unable to forge attractive future trajectories of fair and sustainable societies?

Our study shows that there are at least two ways in which this 'educational handicap' can be addressed and remedied. The first is an emphasis on the often neglected 'think-say-do' component of ESD. Highlighting the interaction between critical reflection and pro-social activities is both feasible and profitable, as the success of Tema high school demonstrates. It gestures towards the educational ideas of John Dewey who, apart from critical inquiry, stressed less competitive and more personalized learning - acquiring knowledge by 'doing', plus thinking and cultivating teamwork (Dewey 1925; Dewey 1938).

The second way of re-imagining ESD was implicit in teachers and students' comments on the vagueness and paucity of sustainability understood as a story. What is often overlooked in teaching sustainability is that the most fascinating narratives that have nourished human

\footnotetext{
${ }^{22}$ Glimpses of such balance could be seen at the Tema school in Ghana. Norway has a long tradition of schooling in 'pro-sociality', but, as I have argued, both teachers and students are increasingly pressed to preach and practice a competitive ethos.
} 
imagination since time immemorial - from Adam and Eve, to King Midas, Aladdin's Lamp, Dr. Faustus, the idea of carpe diem, and even soap opera versions of the American Dream watched the world over - have to do with extravagance and abundance. The Norwegian, Ghanaian and Chinese students are all drawn to the myths of the hedonist cornucopia in the same way they are not drawn to the penitential story of conservation and restraint. The magic passage from rags to riches and stories of 'slumdog millionaires' feed people's imagination in developed and developing countries alike.

As suggested by our Ghanaian and Chinese interviewees, one way of countering this trend would be to unearth ecologically-charged, indigenous narratives and weave them into the UN vision of a sustainable development. As things stand, existing, 'Spartan' narratives about a sustainable world are bereft of compelling images and protagonists that would defy the fatal attraction of the ever more seductive - and globalized - stories of success and excess.

To conclude - lurking behind our interviewees' comments on ESD is a call for a civilizational transformation to overhaul the contents of the old, competitive, carbon-based and efficiency-obsessed modernity. But this educational transformation demands a more sophisticated approach to existing educational visions than the mere insertion of environmental ethics into school curricula, or a more vigorous critique of 'ecocidal modernity'. We cannot ignore the mythical strength and attraction of carbon modernity: an upbeat story which has, for a long time now, promised better, more exciting and fulfilled lives for many of earth's citizens.

Our encounters with teachers and students from Norway, China and Ghana suggest three ways forward: Firstly, enhancing the oikos in education everywhere calls for more mythogenic effort: forging a compelling set of narratives about the beauty of future sustainable societies - stories which would provide each cultural community with its own 'home' in which to think and act towards saving the planet. Secondly, as the Ghanaian and Norwegian teachers have suggested, the narrative of a sustainable future would get a substantial lift from a more vigorous interaction with vernacular, ecological lore and wisdom, such as Ghanaian and Norwegian folktales. ${ }^{23}$ But, most importantly, teaching sustainability in all corners of the world needs a shift of emphasis from 'sustain' to 'ability'.

\footnotetext{
${ }^{23}$ A similar claim about China has been made by James Miller in the article 'Is Green the New Red? The Role of Religion in Creating a Sustainable China.' In Religious Innovation for a Sustainable Future: Perspectives from Norway, Ghana, China, and India, ed. Nina Witoszek, Journal of Nature and Culture, Vol. 8, 2013.
} 
References

Andresen, E., and Henningsen, R. (2013). Radar: Samfunnsfag vg1 og vg2. Oslo: Cappelen Damm.

Birkenes, J. and Østensen Solberg, U.Ø. .2014. Geografi. Underveis series. Oslo: Gyldendal

Bonnett, M. 2004. Retrieving nature: Education for a post-humanist Age. United Kingdom: Blackwell Publishing.

Bruner, J. 1986. Actual Minds, Possible Worlds. Cambridge, Mass.: Harvard University Press.

Bruner, J. 2002. Acts of Meaning. Cambridge, Mass.: Harvard University Press.

Brundtland Report: Our common future (1987). Oxford: Oxford University Press.

CERES21, http://www.ceres21.org/

Cordington, S. 2010. Planet geography. Solida Star Press.

Christensen, K.G. and T. Kristensen.1997a: Interessekonflikter i bruk av naturressurser - en utfordring i miljфundervisningen. Rapport nr. 1 fra MUVIN 2 i Norge. Retrieved 2 May 1, 2013 from http://www-bib.hive.no/tekster/muvin/ Accessed 5 May 2015

Christensen, K.G. and T. Kristensen.1997b: Miljøundervisning i grunnskolen - hvordan har skolene møtt utfordringen som den nasjonale satsingen innebarer? Retrieved 2 May 2013 from http://www-bib.hive.no/tekster/hveskrift/rapport/1997-1/del1.html Accessed 5 May 2015.

Dangbey, A. D-Q. 1997. Social studies for junior high schools. Accra: Aki-Ola series.

Digernes, A.N., Ersland, G.A., Holden Hoff, R., Dahl Martinsen, K. (2003) Historie.vgs Verden og Norge etter 1850. Oslo: Gyldendal.

Dongxia, S. (2013a). Teaching sustainable education in China: the case of Xiehe secondary School. Interviews with students part 1. Center for Development and the Environment, the University of Oslo.

Dongxia, S. 2013b. Teaching sustainable education in China: The case of Xiehe secondary school. Interviews with students, part 2. Center for Development and the Environment, the University of Oslo.

Dongxia, S. 2013c. Teaching sustainable education in China: the case of Xiehe secondary school. Interviews with teachers, part 1. Center for Development and the Environment, the University of Oslo.

Dongxia, S. 2013d. Teaching sustainable education in China: The sase of Xiehe Secondary School. Teachers, part 2. Center for Development and the Environment, the University of Oslo. 
Du, Y. 2008. A decade review on ESD in China. Journal on Education for Sustainable Development in China, 1, 1-2.

Edwards, A.R. 2005. Sustainability revolution: portrait of a paradigm shift. Gabriola, BC: New Society Publishers.

Eisenstadt, Shmuel (ed). (2000) Multiple modernities. Special Issue of Daedalus, Winter.

Gough, S. and Scott, W. 2003. Key issues in sustainable development and learning. London: Routledge.

Halm, E. 2013. Teaching sustainability in Ghana: The case Tema international high school. Report. Center for Development and the Environment, the University of Oslo.

Hellevik, O. 2008. Jakten på den norske lykken: Norsk Monitor 1987 - 2005 (The Pursuit of Norwegian Happiness: Monitoring Norway in 1987-20005). Oslo: Universitetsforlaget

IAEEA 2002: Civic education study i Norge. International Association for the Evaluation of Educational Achievement. http://www.ils.uio.no/forskning/avsluttedeprosjekter/civic/rapporter/rapporter2.html Accessed 14 June 2014.

Interview with SOS Ghana on quality education for a sustainable future. 2016. TV3

NewDay. https://www.youtube.com/watch?v=o2R2WjjUfBY Accessed 17 May 2016.

Integrated science for high schools in West Africa 1993- to date. 2005. Accra, Aki-Ola series.

Jorgensen, A.K. 2003. Consumption and environmental degradation: A cross-national analysis of ecological footprint. Social Problems 509, no. 3: 374-394.

Jakalia, A. 2013. Teaching sustainability in Ghana: the case of Winneba high school. Report. Center for Development and the Environment, the University of Oslo.

Kopnina, H. 2012. Education for sustainable development (ESD): the turn away from 'environment' in environmental education? Environmental Education Research 18, no. 5, 699-717.

Laumann, K. 2007. The missing story. Education for a sustainable development in Norway. Master thesis, SUM, The University of Oslo.

Madsen, P.A., Killerud, I.H., Roaldset, H., Bjølgerud Hansen, A., Sæther, Ø. 2013. Perspektiver - Historie vg2/vg3. Oslo: Gyldendal.

Midttun, A. and N. Witoszek. 2015. Green transition in energy and transport: Towards ecomodernity. London: Routledge.

Miller, J. 2013. Is Green the New Red? The Role of Religion in Creating a Sustainable China. Religious Innovation for a Sustainable Future: Perspectives from Norway, Ghana, China, and India, ed. Nina Witoszek, Journal of Nature and Culture, Vol. 8, 2013. 
Martiniusen, E. 2012. Jørgen Randers mener folk star i veien. Morgebladet. July.

https://morgenbladet.no/samfunn/2012/mener_folket_star_i_veien Accessed 4 May 2015.

National report of Ghana on the development of education. 2004.

http://www.ibe.unesco.org/International/ICE47/English/Natreps/reports/ghana.pdf Accessed 17 May 2016.

Newig, J., Vos, J.P, and Monstad, J. (2008) Governance for Sustainable Development: Coping with Ambivalence, Uncertainty and Distributed Power. London: Routledge.

Norwegian Ministry of Foreign Affairs. 2002. National Strategy for Sustainable Development. Oslo.

Norwegian Ministry of the Environment. 1989. Miljø og utvikling. Norges oppfølging av Verdenskommisjonens rapport. St.meld. nr. 46 (1988-89).

Norwegian Ministry of the Environment. 1994. Environmental education in Norway - A systemic approach. Oslo: Falch Fargetrykk.

Norwegian Ministry of the Environment (1996-97): Miljøvernpolitikk for en baerekraftig utvikling. Dugnad for framtida. White Paper 58. Oslo.

Norwegian Ministry of Environment.1988-89. Miljф og utvikling. Norges oppfфlging av Verdenskommisjonens rapport. White Paper 46. Oslo.

Norwegian Directorate for Education and Training (2006b): Laereplan i naturfag.

Kunnskapslфftet.

http://www.utdanningsdirektoratet.no/templates/udir/TM_UtdProgrFag.aspx?id=2103

Accessed 2 May 2014

Norwegian Directorate for Education and Training. 2006c: Lareplan i samfunnsfag.

Kunnskapslфftet.

http://www.utdanningsdirektoratet.no/templates/udir/TM_UtdProgrFag.aspx?id=2103

Accessed 2 May 2014.

NOU 2014-2015: 7/8 - Regjeringen.no

Outline of China's national plan for medium and long-term education reform and development 2010-2020. 2010 Bejing 12 July.

Ott, A. 2014. Museums: learning centers and education for sustainable development: practices and possibilities in the Oslo Area. Master Thesis. SUM, the University of Oslo.

Quatery, S.M. 2000. Ghana and the wider world. Primary Environmental Studies 6. (London: Macmillan)

Randers, J. 2012. 2052: A Global forecast for the next forty years. London: Chelsea Green Publishers. 
Randers, J. 2014. The climate paradox updated - planetary limits. Lecture at the international conference 'Climate Psychology and Solutions', the Norwegian Business School, 21 October 2014. https://www.bi.no/om-bi/aktivitetskalender/climate-psychology-and-solutions/

Ribeiro Koelch, E. 2014. Constructing Norwegianness in school: exploring how school activities in nature are connected to the development of an important facet of Norwegian identity. Master thesis, Oslo Høyskole.

Robotttom, I. 2012. Changing discourses in EE/ESD. A role for professional selfdevelopment. In Stevenson, R.B., Brody, M., Dillon, J. and Wals A.E.J., (Eds). International Handbook of Environmental Education Research. London: Routledge.

Saetre, P.J. 2002. 'Natur-samfunn og miljøfaget i lærerutdanninga er en saga av blott!' Norsk pedagogisk tidsskrift Nr. 05: 395-402.

Sipos, , Y.R, Battisrii, B., \& Grimm, K. 2008. Achieving transformative sustainability learning: Engaged head, hands and heart. International Journal of Sustainability in Higher Education 9, no 1: 68-86.

Sterling. S. 2008. Sustainable education - towards a deep learning response. Policy and Practice: A Development Education Review 6. Spring: 63-68.

Tian, Y. and C. Wang (2015) 'Environmental Education in China: Development, Difficulties and Recommendations, Journal of Social Science Studies, vol 3, No. 1. See http://www.macrothink.org/journal/index.php/jsss/article/view/7144. Accessed 25 May 2016.

Tian, Q. 2008. 'Chinese ESD policy research.' Paper and presentation at the Regional Workshop on ESD Policy and Implementation: China, Japan and Republic of Korea.Yi, J., \& Wu, P. Report from China Climate Change and Sustainable Development: The Response from Education: The International Alliance of Leading Education Institutes.

Ting, W. 2014 . Education for sustainable development in China. The Journal of Sustainability Education, July 17.

http://www.jsedimensions.org/wordpress/content/education-for-sustainabledevelopment-in-china_2014_06/ Accessed 17 May 2016

UNCED 1992a. Agenda 21. United Nations Conference on Environment and Development. Retrieved 1 March, 2015 from http://www.un.org/esa/sustdev/documents/agenda21/english/agenda21toc.htm Accessed 17 May 2016.

UNESCO (2006): Education for Sustainable Development: 'Concepts.'http://portal.unesco.org/education/en/ev.phpURL_ID=23292\&URL_DO=DO_TOPIC\&URL_SECTION=201.html Accessed 2 May 2015.

UNESCO. 2007. United Nations Decade for Education for Sustainable Development." Retrieved 2 May 2015, from http://portal.unesco.org/education/en/ev.phpURL_ID=27234\&URL_DO=DO_TOPIC\&URL_SECTION=201.html 
Van Marion, P.E, Stølevik, Svendsen, B., Thurhaug, T., Hov, H. Trongmo, Ø., 2013. SENIT: SF Naturfag. Oslo: Gyldendal Undervisning.

Witoszek, N. 2006. Globalization and sustainability: a humanist agenda. Journal for the Study of Religion, Nature and Culture, vol. 11, 3 September.

Witoszek, N. 2012. The Origins of the Regime of Goodness: Remapping the Norwegian Cultural History. Oslo: Norwegian University Press.

Witoszek, N. 2014. Communicating sustainability. Seminar at the Center for Development and the Environment, the University of Oslo, 28 August 2014.

Witoszek, N. 2015. 'Utdanning og Armageddon', Aftenposten, 12 March. http://www.aftenposten.no/meninger/kronikker/Kronikk-av-Nina-Witoszek-Hvordanoke-vare-barns-sjanser-til-a-overleve-7934550.html Accessed 17 May 2016.

Witoszek, N. (2016) 'Ecomodernity as a cultural programme: combining green transition with an educational paradigm shift', Forum for Development Studies, vol. 43, nr 1: 135-155. 